\title{
PERANCANGAN SISTEM INFORMASI GEOGRAFIS RUANG TERBUKA HIJAU DI KOTA MANADO
}

\author{
Silvana Kawulur ${ }^{1)}$, Yaulie Rindengan ${ }^{2)}$, Stanley Karouw ${ }^{3)}$, Jimmy Robot $^{4)}$ \\ ${ }^{1,2,3,4}$ Program Studi Teknik Informatika, Fakultas Teknik, Universitas Sam Ratulangi \\ Jl. Kampus UNSRAT Bahu, Manado, 95115 \\ Telp : (0431) 852959, Fax : (0431) 823705 \\ E-mail : skawulur@gmail.com ${ }^{1)}$,rindengan@gmail.com ${ }^{2}$, stanley.karouw@unsrat.ac.id ${ }^{3)}$ \\ jimmy.robot@unsrat.ac.id ${ }^{4)}$
}

\begin{abstract}
Abstrak
Perkembangan Kota Manado sangat pesat karena meningkatnya jumlah penduduk, sehingga meningkatnya kebutuhan akan tempat tinggal serta sarana dan prasarana. Hal ini menyebabkan perlu adanya keseimbangan antara wilayah-wilayah tersebut. Salah satu faktor untuk menyeimbangkan keadaan lingkungan Kota Manado yang sudah sangat padat yaitu dengan adanya Ruang Terbuka Hijau. Ruang Terbuka Hijau perlu di rencanakan agar dapat mengatur dan mengelola ruang atau lahan sehingga memberikan keseimbangan lingkungan kota secara optimal. Tujuan pengembangan penelitian ini untuk menganalisa dan merancang aplikasi Sistem Informasi Ruang Terbuka Hijau Kota Manado berbasis GIS, dengan menggunakan metodologi DAD (Disciplined Agile Delivery) sebagai metode perancangan sistem dan perangkat lunak Quantum GIS berbasis open source untuk mengolah peta. Hasil yang dicapai adalah dapat menampilkan peta serta mengolah basis data Ruang Terbuka Hijau Kota Manado.
\end{abstract}

Kata kunci: Disciplined Agile Delivery, Quantum GIS, Ruang Terbuka Hijau, Sistem Informasi Geografis

\section{PENDAHULUAN}

Salah satu faktor untuk menyeimbangkan keadaan lingkungan Kota Manado yang sudah sangat padat yaitu dengan adanya Ruang Terbuka Hijau. Keberadaan Ruang Terbuka Hijau sangatlah banyak jenisnya, yaitu Ruang Terbuka Hijau alami dan buatan seperti taman kota, jalur hijau, kebun dan pekarangan, serta hutan kota. Ruang Terbuka Hijau perlu di rencanakan agar dapat mengatur dan mengelola ruang atau lahan sehingga memberikan keseimbangan lingkungan kota secara optimal. Dalam merencanakan Ruang Terbuka Hijau, perencanaan ini sangat diperlukan peta tematik digital. Peta ini yang akan menunjukan lokasilokasi yang layak dijadikan Ruang Terbuka Hijau, karena begitu banyaknya lokasi-lokasi di Kota Manado yang berpotensi sebagai Ruang Terbuka Hijau.

Tujuan dari penelitian ini yaitu Untuk merancang sebuah Sistem Informasi Ruang Terbuka Hijau di Kota Manado berbasis Geographic Information System (GIS), menggunakan metodologi Disciplined Agile Delivery untuk merancang Sistem Informasi Geografis Ruang Terbuka Hijau di Kota Manado, serta menggunakan teknik pemrograman berorientasi objek dengan menggunakan tools open source dan proprietary.

Berdasarkan latar belakang yang telah dijelaskan sebelumnya, diperoleh masalah yang hendak dikaji dalam tugas akhir ini, yaitu bagaimana merancang sebuah Sistem Informasi Geografis Ruang Terbuka Hijau yang dapat mengelola dan menunjukan data-data terkait potensi wilayah Ruang Terbuka Hijau Kota Manado.

\section{LANDASAN TEORI}

Bagian ini akan menjelaskan beberapa teori terkait dengan pengembangan Sistem Informasi Ruang Terbuka Hijau di Kota Manado. Metodologi yang digunakan juga dijelaskan pada bagian ini.

\section{A. Ruang Terbuka Hijau}

Ruang terbuka hijau kota merupakan bagian dari penataan ruang perkotaan yang berfungsi sebagai kawasan lindung. Kawasan hijau kota terdiri atas pertamanan kota, kawasan hijau hutan kota, kawasan hijau rekreasi kota, kawasan hijau kegiatan olahraga, kawasan hijau pekarangan. Ruang terbuka hijau diklasifikasi berdasarkan status kawasan, bukan berdasarkan bentuk dan struktur vegetasinya (Fandeli, 2004) ${ }^{[1]}$.

\section{B. Sistem Informasi Geografis}

Arronoff (1989) ${ }^{[2]}$, mendefinisikan SIG sebagai suatu sitem berbasis komputer yang memiliki kemampuan dalam menangani data bereferensi 
geografi yaitu pemasukan data, manajemen data (penyimpanan dan pemanggilan kembali), manipulasi dan analisis data, serta keluaran sebagai hasil akhir (output). Hasil akhir (output) dapat dijadikan acuan dalam pengambilan keputusan pada masalah yang berhubungan dengan geografi.

Sistem informasi geografis memiliki empat komponen dasar yaitu masukan data, manajeman data, manipulasi dan analisis data dan penyajian data (Aronoff, 1989) ${ }^{[2]}$. Sedangkan menurut Prahasta (2002) ${ }^{[3]}$, SIG dapat diuraikan menjadi beberapa subsistem berikut: 1)Data input: Subsistem ini bertugas untuk mengumpulkan dan mempersiapkan data spasial dan atribut dari berbagai sumber. Subsistem ini pula yang bertanggungjawab dalam mengkonversi atau mentransformasikan format-format data-data aslinya ke dalam format yang dapat digunakan oleh SIG. 2)Data output: subsistem ini menampilkan atau menghasilkan keluaran seluruh atau sebagian basisdata baik dalam bentuk softcopy maupun bentuk hardcopy: seperti tabel, grafik, peta dan lain-lain. 3)Data management : subsistem ini mengorganisasikan baik data spasial maupun atribut ke dalam sebuah basisdata sedemikian rupa sehingga mudah dipanggil, di-update, dan di-edit. 4)Data manipulation dan analysis: subsistem ini menentukan informasiinformasi yang dapat dihasilkan oleh SIG. Selain itu, subsistem ini juga melakukan manipulasi dan permodelan data untuk menghasilkan informasi yang diharapkan.

\section{Metodologi Disciplined Agile Delivery}

Disciplined Agile Delivery Lifecycle ${ }^{[4]}$ memperluas pada siklus konstruksi Scrum dalam tiga hal penting:

a) Ini memiliki proyek fase eksplisit, mengakui bahwa pengiriman tangkas benar benar berulang dalam seri kecil dan dalam lingkup besar.

b) Ini mencakup berbagai macam praktik. Ini termasuk persyaratan awal dan membayangkan seperti arsitektur pada awal proyek untuk meningkatkan kesempatan membangun produk yang tepat dengan cara yang tepat, serta praktek rilis sistem.

c) Ini termasuk praktik lebih kuat. Siklus hidup tokoh ini secara eksplisit mengolah kembali backlog produk dalam slide sebelumnya ke dalam konsep yang lebih akurat dari pekerjaan item daftar peringkat. Tidak hanya tim pengiriman tangkas menerapkan persyaratan fungsional, mereka juga harus memperbaiki cacat (ditemukan melalui pengujian independen atau dengan pengguna versi yang ada dalam produksi), memberikan umpan balik pada pekerjaan dari tim lain, mengambil kursus pelatihan, dan sebagainya.

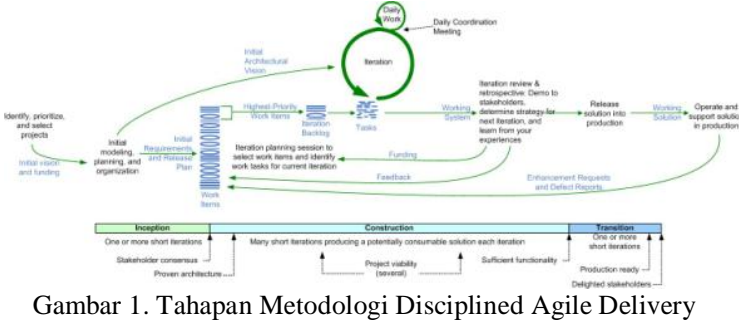

Metodologi ini juga memberikan dokumen dan presentasi dari setiap fase, sebagai target yang harus dicapai sebelum melanjutkan ke fase yang selanjutnya. Untuk kepentingan penulisan paper ini, maka penulis akan membatasi artifak yang akan ditampilkan.

\section{METODOLOGI PENELITIAN}

\section{A. Objek dan Lokasi Penelitian}

Adapun penelitian yang di lakukan untuk menyusun Tugas Akhir ini dilaksanakan di Badan Perencanaan Pembangunan Daerah Kota Manado.

\section{B. Kerangka Penelitian}

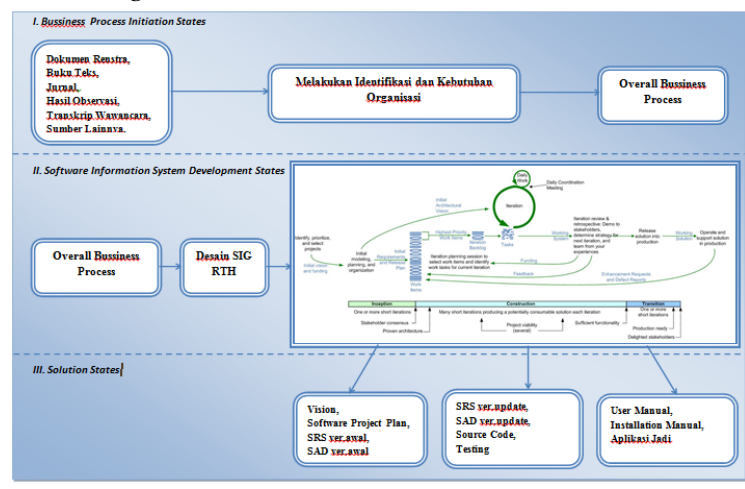

Gambar 2. Kerangka Penelitian

\section{Gambaran Umum Lingkungan Bisnis}

BAPPEDA Kota Manado dibentuk berdasarkan Ketetapan Presiden Nomor 27 Tahun 1978 yang didasarkan pada pertimbangan bahwa dalam rangka melaksanakan kewenangan, kebijakan dan program pemerintah daerah Kota Manado di bidang perencanaan pembangunan daerah perlu dilakukan upaya untuk mewujudkan aparatur pemerintah yang profesional dan berwibawa melalui pendidikan latihan.

Tugas BAPPEDA Berdasarkan Peraturan Daerah Nomor 12 Tahun 2006 tentang Pembentukan, Susunan Organisasi dan Tata Kerja Lembaga Teknis Daerah, Badan Perencanaan Pembangunan Daerah mempunyai tugas melaksanakan urusan rumah tangga Pemerintah Daerah dan tugas pembantuan dibidang perencanaan pembangunan. Visi dan Misi Sebagai bagian integral perangkat daerah Kota Manado, maka visi dan misi BAPPEDA Kota Manado harus mengacu pada Visi dan Misi Kota Manado dengan mencermati berbagai perkembangan terkini. BAPPEDA Kota Manado menetapkan Visi, yaitu: 
"Terselenggaranya perencanaan daerah yang handal membangun Manado Kota Pariwisata Dunia 2010 menuju terwujudnya masyarakat yang aman, berdaya saing, sejahtera, berkeadilan dan bermartabat".

\section{Gambaran Umum Kota Manado}

Kota Manado terletak di ujung utara Pulau Sulawesi dan merupakan kota terbesar di belahan Sulawesi Utara sekaligus sebagai ibukota Propinsi Sulawesi Utara. Secara geografis terletak di antara $1^{0} 30^{\prime}-1^{0} 40^{\prime}$ Lintang Utara (LU) dan $124^{\circ} 40^{\prime} 00^{\prime \prime}$ - $126^{0} 50^{\prime}$ Bujur Timur (BT), dan secara administratif batas-batasnya sebagai berikut:

a. Sebelah Utara dengan Kec. Wori (Kab. Minahasa Utara) dan Teluk Manado

b. Sebelah Timur dengan Kec. Dimembe (Kab. Minahasa Utara) dan Kec. Tombulu (Kabupaten Minahasa)

c. Sebelah Selatan dengan Kec. Pineleng (Kab. Minahasa)

d. Sebelah Barat dengan Teluk Manado (Laut Sulawesi)

Tabel 1. Luas Wilayah Kota Manado Kecamatan

\begin{tabular}{lccc}
\hline \hline KECAMATAN & LUAS ( Ha $)$ & $\%$ & $\begin{array}{c}\text { JUMLAH } \\
\text { KELURAHAN }\end{array}$ \\
\hline \multicolumn{1}{c}{$(1)$} & $(2)$ & $(3)$ & $(4)$ \\
\hline Malalayang & $1.720,75$ & 10,94 & 9 \\
Sario & 193,25 & 1,23 & 7 \\
Wanea & 785,25 & 4,99 & 9 \\
Wenang & 336,95 & 2,14 & 12 \\
Tikala & $1.511,80$ & 9,61 & 12 \\
Mapanget & $5.820,95$ & 37,02 & 11 \\
Singkil & 467,75 & 2,98 & 9 \\
Tuminting & 431,00 & 2,74 & 10 \\
Bunaken & $4.458,30$ & 28,35 & 8 \\
& \multicolumn{2}{c}{} \\
\hline \multicolumn{1}{c}{ JUMLAH/ Total } & $15.726,00$ & 87 \\
\hline Sumber: Manado Dalam Angka Tahun 2010
\end{tabular}

Berikut adalah tampilan peta Kota Manado di Provinsi Sulawesi Utara.

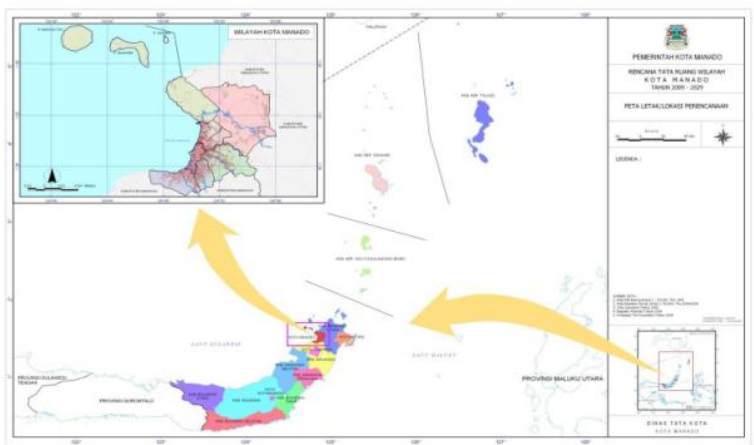

Gambar 3 . Peta Letak Wilayah Kota Manado di Provinsi Sulawesi Utara

\section{PEMBAHASAN}

Pada bagian pembahasan, penulis akan menampilkan setiap artifak terkait dari setiap proses dan aktivitas yang dilakukan pada setiap fase menurut metodologi DAD. Setiap fase memiliki tujuan aktivitas proses, dimana aktivitas proses tersebut menghasilkan artifak atau dokumentasi aplikasi yang dibangun. Seperti yang disebutkan diatas, DAD membagi tahapan pengembangan piranti lunak menjadi inception, construction dan transition.

\section{A.Tahap Inception}

Tujuan dari tahap awal atau tahap inception ini yaitu menderfinisikan batasanbatasan lingkungan proyek, estimasi kasar terhadap biaya dan waktu mendefinisikan resiko, menentukan kelayakan serta mempersiapkan lingkungan pengerjaan proyek.

Output yang akan dihasilkan dari aktivitas tahap inception yaitu dokumen Vision, Software Project Plan, SRS ver.awal, SAD ver.awal.

Untuk estimasi waktu pengerjaan sebanyak 3 bulan dengan jumlah tim pengembang 4 orang. Sementara untuk kelayakan financial aplikasi SIG dihitung dengan tools Net Present Value (NPV), Return on Investment (ROI) dan Break Event Point (BEP). Total Yearly NPV sebesar Rp. 3.018.868 (dalam empat tahun) dengan ROI 87,5\% dan BEP 3,62 tahun.

Berikut adalah fungsionalitas utama dari aplikasi yang akan dikembangkan dapat dilihat pada Tabel 1.

Table 2. Fungsionalitas Utama Sistem Informasi Geografis Ruang Terbuka Hijau di Kota Manado

\begin{tabular}{|c|c|}
\hline \multicolumn{2}{|c|}{ Functional Requirements } \\
\hline \multirow{2}{*}{$\begin{array}{l}\text { 1. Melakukan } \\
\text { Login }\end{array}$} & 1.1 Login Administrator \\
\hline & 1.2 User Viewing \\
\hline \multirow[t]{2}{*}{ 2. Viewing Data } & $\begin{array}{l}\text { 2.1 User dapat melihat data } \\
\text { (Peta RTH dan Basis Data } \\
\text { RTH) }\end{array}$ \\
\hline & $\begin{array}{l}\text { 2.2 User dapat memilih data } \\
\text { (Peta RTH dan Basis Data } \\
\text { RTH) }\end{array}$ \\
\hline \multirow[t]{4}{*}{ 3. Mengelola Data } & $\begin{array}{l}3.1 \text { Admin dapat melakukan } \\
\text { input data }\end{array}$ \\
\hline & $\begin{array}{l}\text { 3.2 Admin dapat melakukan } \\
\text { edit data }\end{array}$ \\
\hline & $\begin{array}{l}\text { 3.3 Admin dapat melakukan } \\
\text { delete data }\end{array}$ \\
\hline & $\begin{array}{l}\text { 3.4 Admin dapat melakukan } \\
\text { cetak data }\end{array}$ \\
\hline \multicolumn{2}{|c|}{ Non Functional Requirements } \\
\hline $\begin{array}{l}\text { 1. Performance } \\
\text { Requirements }\end{array}$ & $\begin{array}{l}\text { 1.1 Sistem dapat merespon } \\
\text { ke database kurang dari } 10 \\
\text { detik } \\
1.2 \text { Sistem mampu } \\
\text { beroperasi selama } 9 \text { jam dan } \\
5 \text { hari dalam } 1 \text { minggu }\end{array}$ \\
\hline $\begin{array}{l}\text { 2. Environmental } \\
\text { Requirement }\end{array}$ & \begin{tabular}{lr}
2.1 & \multicolumn{2}{c}{ Keadaan lingkunaan } \\
standar, khusus untuk \\
ruangan server & disarankan \\
menggunakan & pendingin \\
ruangan &
\end{tabular} \\
\hline
\end{tabular}




\section{B. Tahap Elaboration}

Elaboration adalah tahap kedua dalam metodologi perancangan sistem yang digunakan. Tujuan dari tahap ini yaitu mengidentifikasikan arsitektur sistem yang akan diimplementasikan serta memodelkan sistem yang akan dirancang.

Output yang akan dihasilkan dari aktivitas tahap elaboration yaitu dokumen SRS ver.update, SAD ver.update, Source Code, dan dokumen Testing.

Dalam metodologi DAD sebelum melakukan perancangan dengan melakukan pemodelan, terlebih dahulu dilakukan metode pengumpulan data yang disusun dalam user story card, yang memuat keinginan para stakeholder mengenai fiturfitur yang akan ada pada Sistem Informasi Geografis Ruang Terbuka Hijau di Kota Manado. Berikut adalah salah satu contoh user story card:

Gambaro 4 . User Story Card

Desain dari Sistem Informasi Geografis ini dirancang meliputi 4 bagian besar berdasarkan dengan proses dan perangkat lunak yang digunakan, yaitu dari proses manual untuk mengumpulkan data, lalu menggunakan perangkat lunak Quantum GIS dalam pengolahan peta, xampp mysql untuk mengolah basis data, serta bahasa C\# untuk melakukan coding.

Gambar 5. Desain Sistem Informasi Ruang Terbuka Hijau

Untuk pemodelan perancangan perangkat lunak digunakan UML yang menyajikan Use Case Diagram untuk menjelaskan functional view, Class Diagram untuk menjelaskan logical view serta storyboard untuk rancangan antarmuka.

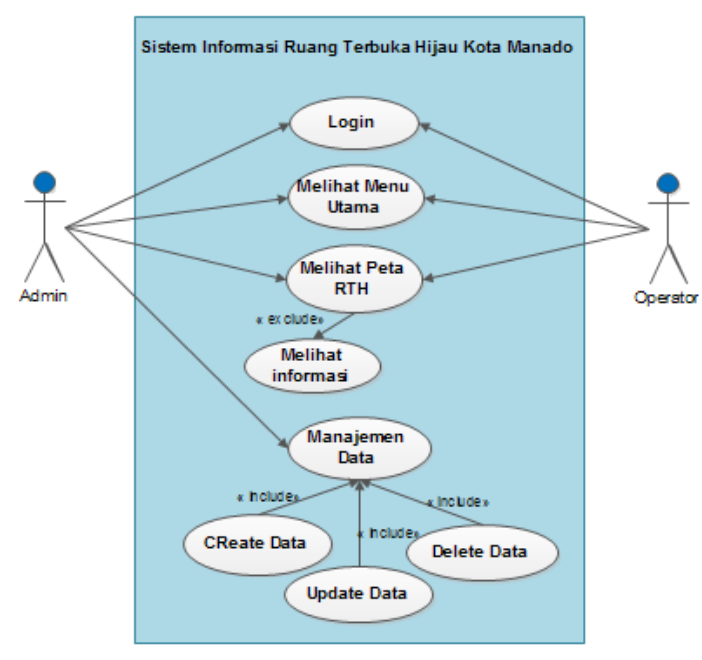

Gambar 6.Use Case Diagram

Berikut adalah beberapa contoh use case description yang merupakan penjelesan dari use case diagram di atas.

Tabel 3. Use Case Description : Login 


\begin{tabular}{|l|l|l|}
\hline Nama Use case & Login \\
\hline Aktor & User \\
\hline Deskripsi & $\begin{array}{l}\text { Use case ini menjelaskan tentang proses masuk ke dalam } \\
\text { aplikasi }\end{array}$ \\
\hline Precondition & $\begin{array}{l}\text { Sistem mempersiapkan untuk menyediakan halaman login } \\
\text { untuk user memasukkan username dan password }\end{array}$ \\
\hline Normal course & Kegiatan Aktor & Respon Sistem \\
\cline { 2 - 3 } & $\begin{array}{l}\text { 2. User akan mengisi } \\
\text { username dan password, lalu } \\
\text { menekan tombol login untuk } \\
\text { masuk ke dalam aplikasi }\end{array}$ & $\begin{array}{l}\text { 1. Sistem akan menampilkan } \\
\text { fungin }\end{array}$ \\
& $\begin{array}{l}\text { 3. menampilkan tampilan } \\
\text { awal }\end{array}$ \\
\hline Alternate course & - \\
\hline Post-condition & $\begin{array}{l}\text { Jika username ataupassword salah, maka sistem akan kembali } \\
\text { menampilkan fungsi login }\end{array}$ \\
\hline
\end{tabular}

Tabel 4. Use Case Description : Melihat Peta RTH

\begin{tabular}{|l|l|l|}
\hline Nama Use case & Melihat Peta RTH \\
\hline Aktor & User \\
\hline Deskripsi & $\begin{array}{l}\text { Use case ini menampilkan submenu untuk melihat informasi } \\
\text { dalam bentuk peta }\end{array}$ \\
\hline Precondition & Sistem menampilkan tampilan peta Ruang Terbuka Hijau \\
\hline Normal course & Kegiatan Aktor & Respon Sistem \\
\cline { 2 - 3 } & $\begin{array}{l}\text { 2. Melihat informasi dalam } \\
\text { bentuk peta }\end{array}$ & $\begin{array}{l}\text { RTH } \\
\text { RTHem menampilkan peta } \\
\text { 3. menampilkan sub menu } \\
\text { yang lain }\end{array}$ \\
\hline Alternate course & - & \\
\hline Post-condition & $\begin{array}{l}\text { User dapat melihat informasi dalambentuk peta yang terdapat } \\
\text { pada aplikasi, setelah itu dapat memilih sub menu lain untuk } \\
\text { melihat basis data RTH }\end{array}$ \\
\hline
\end{tabular}

Tabel 5. Use Case Description : Manajemen Data

\begin{tabular}{|l|l|l|}
\hline Nama Use case & Manajemen Data \\
\hline Aktor & User & $\begin{array}{l}\text { Memodifikasi data dengan cara menambah, mengedit dan } \\
\text { menghapus data }\end{array}$ \\
\hline Deskripsi & Sistem menampilkan pilihan untuk melakukan manajemen data \\
\hline Precondition & Kegiatan Aktor & \begin{tabular}{l} 
Respon Sistem \\
\cline { 2 - 3 }
\end{tabular} \\
\cline { 2 - 3 } & 2. Memodifikasi data course & $\begin{array}{l}\text { 1. Sistem menampilkan } \\
\text { pilihan untuk menambah, } \\
\text { mengedit atau menghapus } \\
\text { data yang ada }\end{array}$ \\
Alternate course & - & $\begin{array}{l}\text { 3. Menampilkan hasil data } \\
\text { baru yang telah diubah }\end{array}$ \\
\hline Post-condition & Jika data tidak valid maka akan dberi pemberitahuan \\
\hline
\end{tabular}

\subsection{Tahap Construction}

Construction adalah tahap ketiga dalam perancangan sistem yang digunakan. Tujuan utama fase construction adalah membangun dan menguji sistem serta mendapatkan dokumentasi yang mendukung.

Artifak dokumen yang dihasilkan pada tahap ini yaitu User Manual dan Installation Manual.

Lingkungan komputer yang akan digunakan telah terkoneksi dalam satu jaringan menggunakan jaringan LAN. Berikut adalah arsitektur fisik jaringan LAN tersebut:

\section{Gambar 7. Arsitektur Jaringan Fisik LAN}

Berikut adalah storyboard rancangan antarmuka yang di rancang beserta dengan hasil dari aplikasi Sistem Informasi Geografis Ruang Terbuka Hijau Kota Manado.

Gambar 8. Storyboard Rancangan Antarmuka

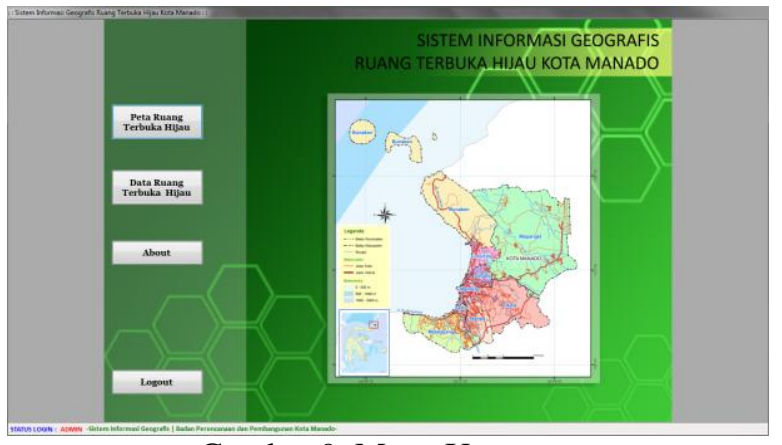

Gambar 9. Menu Utama

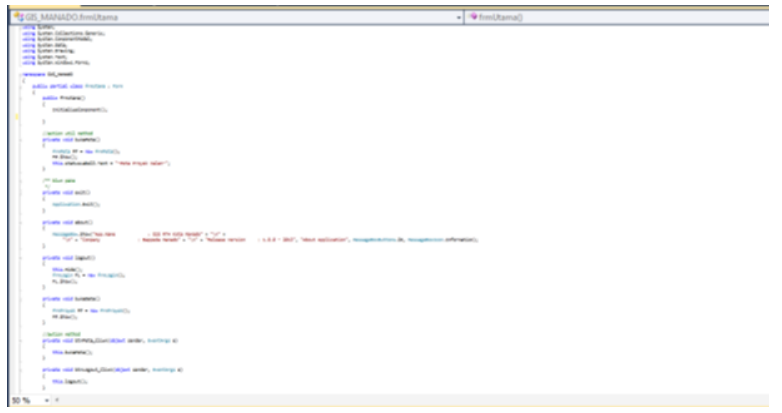

Gambar 10 . Script Menu Utama 


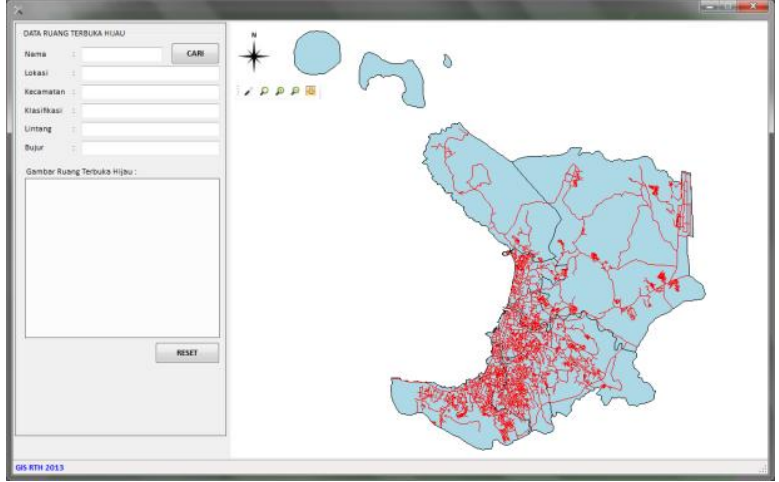

Gambar 11. Halaman Peta RTH

\section{DAFTAR RUJUKAN}

[1] Denny, Feasibilty Studi Ruang Terbuka Hijau Kota Manado, Bapedda, 2011.

[2] Arronoff.S, Geographic Information System: A Management Perspective, WDL Publications, Ottawa Canada, 1989.

[3] Prahasta, Konsep-konsep, Dasar Sistem Informasi Geografis, Bandung, 2002.

[4] IBM, Advanced Disciplined Agile Delivery, IBM Corporation, 2011.

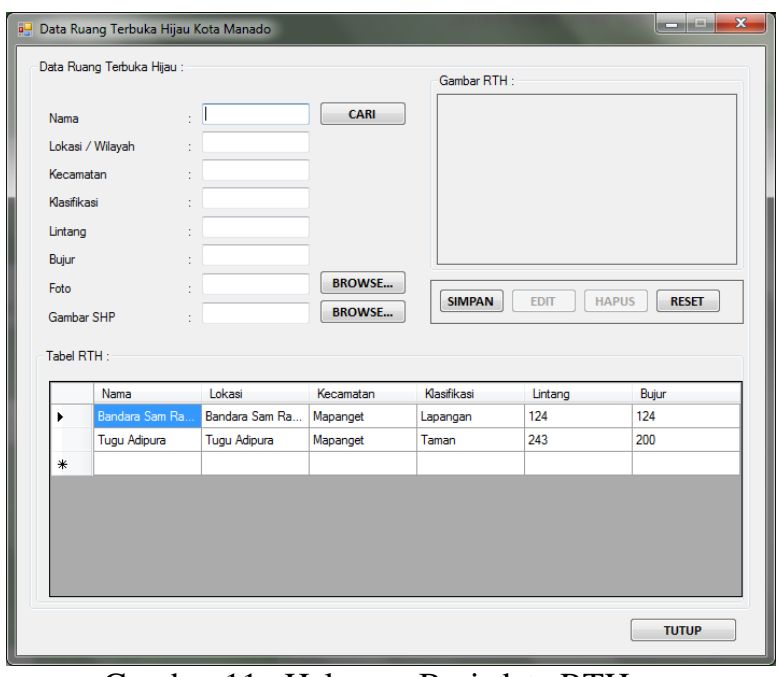

Gambar 11. Halaman Basisdata RTH

\section{SIMPULAN DAN SARAN}

Berdasarkan penelitian ini maka dapat disimpulkan sebagai berikut:

1. Sistem Informasi Geografis Ruang Terbuka Hijau di Kota Manado ini dapat dirancang dengan menggunakan metdologi DAD, perangkat lunak yang bersifat open source serta UML sebagai media untuk memodelkan sistem.

2. Dengan adanya aplikasi Sistem Informasi Ruang Terbuka Hijau Kota Manado ini dapat diperoleh informasi berupa basis data dan peta Kota Manado yang berisikan informasi mengenai Ruang Terbuka Hijau Kota.

3. Metode yang digunakan dalam perancangan sistem ini menggunakan metodologi Disciplined Agile Delivery, sehingga dirancang secara sistematis dan menghasilkan dokumen-dokumen yang sangat berguna.

4. Dengan menggunakan metodologi DAD juga harga yang dikeluarkan untuk merancang perangkat lunak sangatlah ekonomis.

5. Informasi yang diberikan oleh aplikasi ini yaitu mengenai Ruang Terbuka Hijau buatan yaitu berupa taman kota, lapangan dan hutan kota. 